地すべり 第 27 巻 第 4 号

Journal of Japan Landslide Society 27-4 (1991)

\title{
空中写真測量による地す心゙り情報の提供とすべり面の解析
}

一長野市広瀬地区に発生した地すべり地への応用——

\section{Landslide Behaviour Information and Slide Surface Analysis by Photogrammetry -Application to Landslide Area Occurred in Hirose District in Nagano City-}

\author{
吉澤孝和* 丸山昌義**，長尾 勲** \\ Norikazu Yoshizawa Masayoshi Maruyama Isao Nagao \\ 村瀬孝三** 西澤茂高*** 三澤敏 雄*** \\ Kouzou MURASE Shigetaka Nishizawa Toshio Misawa \\ 根岸六郎*** \\ Rokurou NEGISHI
}

\begin{abstract}
Photogrammetry technique is applied to landslide behaviour monitoring and underground slide surface analysis in this paper. The landslide behaviour information necessary to measure of disaster reduction and prevention can be obtained speedily, correctly and safely by this technique. Three dimensional displacement of ground objects such as rocks, trees, farms and various artificial structures can be traced by photogrammetries taken at different recording chance. Analyzing these data, moving direction and velocity of sliding block is distinguished. Depth and shape of the underground slide surface can be presumed by least square method. Accordingly, warning region of the landslide is demarcated on a map. This paper demonstrates utility of the photogrammetry applied to observation and analysis of landslide occurred in Hirose district in Nagano city.
\end{abstract}

キーワード : 空中写真測量, 地すべり情報, 動態観測; すべり面推定

\section{1. はじめに}

測量によって地すべり地の地下すべり面の位置と形状 を推定する研究として、これまで報告してきたものは 地表の変状の激しい時期を過ぎた地すべり地において, トータルステーション方式の地上測量で得られた地表変 位データを解析したものである1) 4)。

一般に地すべりの発生後ある程度の日数を経過すれば 地表に発生した段差や亀裂の成長速度は減速する。しか し段差や亀裂で分断された土塊自体はな挆緩慢な移動を 続けていく。この現象は「地下に形成されたすべり面の 上を, 段差や亀裂で分断された地すべり土塊がほぼ剛体 的な状態を保って移動している」ことを意味するものと 考光られる。これまでの研究の解析理論はこの点に着目 して組み立てたものである ${ }^{2), 3)}$

地すべりが発生した場合，防災対策上直ちに必要とな る情報は「地すべり土塊の移動方向と移動速度, および 地すべり変動の発生している範用」である。またボーリ ング調査や地すべりの機構解析括よび対策工事計画等に

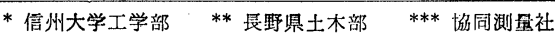

おいて必要とされるものに「地下に発生したすべり面の 深さと形状に関する推定」という問題がある。これらの 情報はいずれる本研究の地表変位観測データを解析して 得ることができる。しかし地上測量は地すべりの活動が 激しい場合, かなりの危険を伴う。また, 現地への立ち 入りを待機している間に活動がほとんど停止して，観測 の機会を逸してしまうような地すべりもある。

地上測量のこのような不都合を解決するために, 筆者 らは地すべり発生時の早期動態観測に空中写真測量の利 用を試みた。1989年10月に長野市芋井広瀬地区に発生し た地すべりに適用したところ，かなり有効な手法である ことが分かったのでここに報告したい。

わが国で，地すべりの動態観測に空中写真測量が用い られたのは, 記録に残っているものとしては亀ノ瀬地す ベりが最初である。1967年 2 月から1968年 3 月までに合 計11回の空中写真測量がなされ，この期間に和ける水平 移動量21２2mを検出している。対空標識は人工地物を 含めて約 400 点設置された。この地すべりに対して空中 写真測量が採用された理由は, 53ha といら地すべり規 模の広大さ, 地上測量では対処し難い複雑な地形, 地表 
変状の激しさ等であった。打荻 ${ }^{6)}$ はこの測量 成果を，平面図招よび主要断面図上に拈ける 移動ベクトル図の作成，地表断面形状の変遷 の連続追跡等に応用している。近年の研究と しては地附山地すべり（1985年 7 月発生）に 空中写真測量を利用したものがある。長岡7) は地すべり発生前後の空中写真を用いて, 平 面四上に拈ける地表の諸点の変位ベクトルを 求め, 頭部滑落崖付近で約 $50 \mathrm{~m}$, 中部一带で 約 $100 \mathrm{~m}$, 脚部より下方の領域で約 $150 \mathrm{~m}$ の移 動量を検出した。この研究では対空標識を用 いず，変位追跡点として家屋や道路上の物体 などの地物13点を選び，地すべり前後の写真 上で同一物体であることを確認して追跡して いる。

このような在来の研究と本研究との立場の 違いを要約すると次のようになる。

1）地すべり対策の適切な指針となり得る 地すべり情報の早期提供技術，すなわち地す べり発生時の危険な条件下でも実施可能な早 期動態観測と解析システムを開発すること。

2）対空標識を設置せずに各種の地物（後 述）を利用した地表变位追跡手法の検討，拧 よび変位追跡点の座標測定精度を向上させ， $10 \mathrm{~cm}$ 程度の変位を検出する手法の研究。

3）変位ベクトル図の作成のみならず，観 測データを，各種投影断面図上に括ける地下 すべり面の位置と形状の推定, 平面図上での 地すべり影響圈の推定解析等に利用するこ と。

\section{2.＼cjkstart地すべりの地の概況}

本研究の対象とした地すべりは，長野市芋井大字広瀬 地区を南流する達橋沢の右岸斜面に発生した。図一に示 すように，農道直下の水田地带とその下方に続く山林地 帯が，達橋沢に向かって幅約 $50 \mathrm{~m}$ ，長さ約 $60 \mathrm{~m}$ の範囲に わたって地すべりを起こしている。

飯綱山の南方に位置し背後に飯綱高原を控えるこの地 域は, 火碎岩層と泥岩層とが指交関係で接する複雑な地 質を呈している。今回の地すべりの発生した場所は，過 去における巨大崩壊の末端部にあたり，基盤を構成する 泥岩層を古期地すべりの崩積土が被覆している。地すべ りは泥岩層と崩積土との境界付近をすべり面として発生 したものとみられる。

この地すべりの兆候が発見されたのは1989年10月 3 日 で，それから約 5 日間にわたり顕著な活動が認められた。 それ以後の活杪はほとんど恋められず現在に至っている。 現地で観測された地すべり挙動の概要を以下に示す(図一

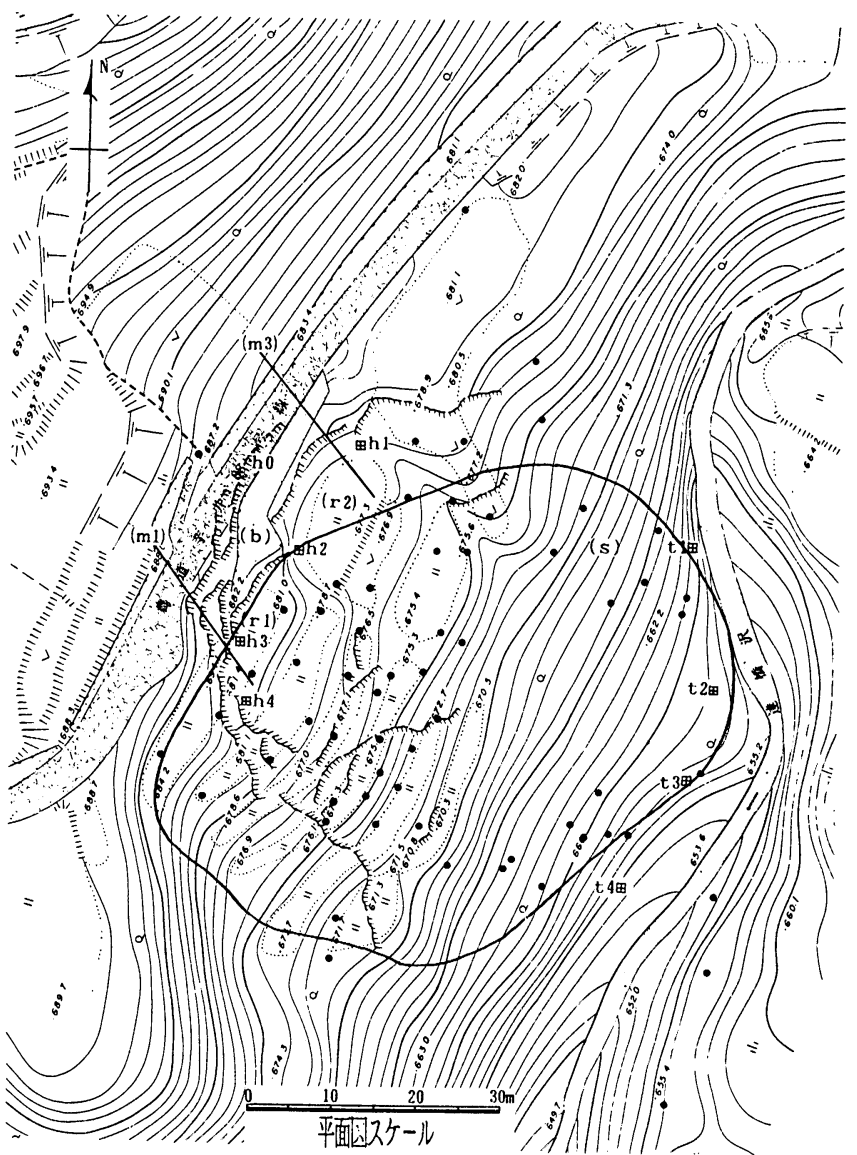

図-1 地すべり地一帯の平面図(地表の変化状況は1989年10月 5 日現在のもの) $\mathrm{m} 1, \mathrm{~m} 3=$ 伸縮計 $\mathrm{h} 1, \mathrm{~h} 2, \mathrm{~h} 3, \mathrm{~h} 4=$ 頭部亀裂発生点 $\mathrm{t} 1, \mathrm{t} 2, \mathrm{t} 3, \mathrm{t} 4=$ 脚部変状境界点

(r1), (r2) =水田 (s)=杉林 (b)=ブロック程み㩁壁

黒丸は空中写真上で計測した变位追跡点, 奏線で囲んだ範罒は (5・1) で 推定した地すべりの影䋨範四

1 参照)。

[10月 3 日]この日の午後, 農道芋井88号線の直下の 水田（rl）に幅 $5 \sim 10 \mathrm{~cm}$ の亀裂 (h2) を発見した。䅖裂 は完全には連続しておらず，断続的な馬蹄形状を呈した。 地域一帯の側部や末端部には地すべりの変状を確認でき ず。19：30より開始した伸縮計 $(\mathrm{m} 1)$ による龟裂の開口 速度は $5 \sim 8 \mathrm{~mm} /$ 時。

〔10月 4 日〕 $8: 00$ に打ける移動速度は $30 \mathrm{~mm} /$ 時。三 次クリープ理論による崩買時刻を正午過ぎと予測するも 崩壊には至らず，頭部の龟裂（h2）は連続した。その段 差は, 朝の $0.3 \mathrm{~m}$ が㡺には0. $5 \mathrm{~m}$ となる。 $12: 30$, 地すへ り脚部の変状を確認。(t1), (t3) の付近で盛り上がりや 亀裂を発見。その位置は河川との最接近部に扣いて川休 からの比高約 $3 \mathrm{~m}$, 距離 $3 \sim 5 \mathrm{~m}$ 。また地すへり地斜面 の下半部の杉林 (s) で樹木の傾動が始まる。道路值下の 水田 (r2) では湧水発生。19：00に拈ける伸縮計 (m1), （m3）による移動速度はそれぞれ 80, 200mm/時。

〔10月5日〕 0:00から4:00までの間に沶いて，伸縮 
計（m1)，(m3) による移動速度はそれぞれ 100,200mm/ 時を記録した。これをピークとして次第に減速へと向 かう。6:00頃, 水田（r2）は湧水による水溜りとなる。 また水田（r1）の一帯が盛り上がり始める。朝方より, 農道に亀裂（h0）が発生して成長を続ける。夕方にはブ ロック積み擁壁 (b ) の沈下が顕著となる。17：00頃, 地 すべり中央末端部（t3）で幅約 $3 \mathrm{~m}$ の小崩落が川に向か って発生した。

〔10月 6 日〕伸縮計による移動速度は減速を続け, 夕 方には $10 \mathrm{~mm} /$ 時以下となる。末端部では朝と夕方に小 崩落あり。この日までに，地すべり土塊全体が達橋沢へ 押し出すことはなかったが，沢ギリギリまで亀裂などの 変状が発生した。

[10月 7 日] 夕刻の移動速度は $0 \sim 1 \mathrm{~mm} /$ 時となる。 この日以降の変状はみられない。

\section{3. 空中写真測量による変位計測} 3.1 空中写真の撮影

この地すべり地に対して空中写真の撮影を行なったの は，1989年10月 5 日15時24分と10月10日14時22分の 2 回

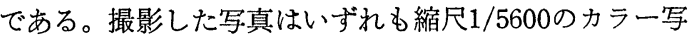
真である。上記のように，10月 6 日以降 地すべりの移 動量は激減している。最初の撮影があと 1 日遅れた場合 には，写真測量では地表物体の変位を検出できなかっ た。よって最初の写真撮影は地すべりの兆候を発見した ならば一刻も早く実行することが大切なポイントと言兄 る。

な打地すべりの発生前の $1 \sim 2$ 年以内に撮影した現地 の空中写真があれば，それと地すべりによる変動後の写 真とから地表物体の変位を計測できる。しかし計測の可 能な点の数はかなり限定されるので，上記のように地す ベりの発生直後の写真のほうが望ましい。

\section{2 変位追跡点の選点とプリッキング}

地すべり地内に変位追跡用の対空標識を設置すること は，地すべりの活動が激しい場合には不可能である。ま た仮に設置してもそこに亀裂などが発生すれば変位追跡 点としての役割をなさない。よって本研究では前後 2 回 の撮影による写真（10月 5 日撮影を写真A，10月10日撮 影を写真 B と呼ぶ）の上で共通に識別でき，乙か子地表 に発生した亀裂や段差から十分に離れている地物を変位 追跡点として選点した。これらは次の諸点である。

1)地表に露出した岩のかど，2)識別しやすい小石等, 3)道路上の目印，4)推壁上の目印，5)畑の中の諸点（農 作物の境界点・点在する小物体), 6)水田（稲の切り株. 畴道の屈曲点)，7）雑草地の中の裸地の形態の特異点,

8)森林の中の樹木の頂点

これらの変位追跡点のらち，7）と8)は計測作業上精度 の確保が困難な目標点である。しかし地すべり地の中部
から脚部は倠草地や㷊林のため，やむを得ず選定したも のである。

選点にあたっては上記の写真を 6 倍に引伸したカラー 写真を用いた。写真上に選点した各測点の位置を，撮影 日の異なる写真 $\mathrm{A}$ と写真 $\mathrm{B}$ のポジフィルム上に正確に移 写するために移写器 (PUG4) を使用した。移写器は, 左側に写真 $\mathrm{A}$ ，右側飞写真 $\mathrm{B}$ のポジフィルムをセットし 選点する目標点を中心として同時実体視を行ない，6〜 24倍の範囲で縮尺を統一し，両写真の同一地点が完全に 一致するようにメスマークにより微調整して，メスマー クの位置を機械的にプリック（刺針）する機械である。 両写真にプリックする位置の精度は0.02mm, 刺針孔の 直径は $0.05 \mathrm{~mm}$ である。

変位追跡点として選点プリックした箇所は, 総計 116 点である。この中には雑草地が14点, 樹冠部が 28 点含ま れている。

\section{3 モデルの標定および変位追跡点の座標值の計測}

10月 5 日撮影の写真Aは, 他の目的で図化作業を行 ならために一次の空中三角測量〔使用機械：解析図 化機（DSR 11），使用計算式：多項式法]を実施してあ る。

本研究では，A，B両写真から測定した同一の変位追 跡点の相対移動量をより正しく求めることに重点が置か

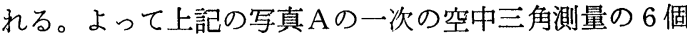
のパスポイントを標定点と仮定して，次のような二次の 空中三角測量を行なった。すなわち写真 Bのモデルは写 真Aと撮影日が異なるために主点位置がずれており，上 記のパスポイントの写らない部分や同一点として移写で きないものがある。そこでA，B両写真に共通に写って いる明瞭な地物で，地すべり变動の影響を受けない場所 を8 個所選点してA，B両ポジフィルムに移写を行ない， '写真Aに準拠した二次の空中三角測量（解析図化機，計 算式は一次と同じ）によって8個のパスポイントの成果 を求めた。標定結果を次に示す。

写真Aのモデルの標定残差の中等誤差 :

平面座標值 $(X, Y): \pm 5.5 \mathrm{~cm}$ 標高 $(H): \pm 6.3 \mathrm{~cm}$ 写真 B のモデルの標定残差の中等誤差 :

平面座標值 $(X, Y): \pm 9.7 \mathrm{~cm}$ 標高 $(H): \pm 7.2 \mathrm{~cm}$

変位追跡点の座標值の計測には上記の解析図化機を使 用した。写真 A，Bのそれぞれについて変位追跡点を整 理番号順に写真座標值として測定し，同時に解析図化機 に内蔵されているコンピュータにより現地の座標值に变 換してハードディスクに格納した。

座標測定の精度に関しては，上記の二次空中三角測量 のパスポイントの精度は土 $9.7 \mathrm{~cm}$ 以内であるが, 個々 の変位追跡点についてはさらにプリック䛊差が介入する。 そのため測定条件のよい目標では $\pm 12 \sim 15 \mathrm{~cm}$ 程度, 測 定条件の悪い雑草地や森林地帯では $\pm 30 \sim 50 \mathrm{~cm}$ 程度を 
見迄んで打く必要がある。な特本研究では, プリック誤差, 標定誤差, 読定誤差に関す る実験を行なっているが，これについては 別の機会にゆずりたい。

\section{4. 各種の投影面上における地す ベり挙動の観察}

写真 A と写真 B で計測された各測点の三 次元座標値を用いて, 各種の投影面上飞拉 いて地すべりの挙動とその特性を観察する ことができる。

図-2は平面図上に表示した変位追跡点の 移動ベクトルである。印が1989年10月 5 日の位置, その中心から発する直線の先端 は10月10日の位置である。よってこの直線 が 5 日間における移動ベクトルをあらわし， 直線の長さが移動量または 5 日間の移動速 度を示す。な扢この図では移動が認められ ない測点と極端に大きな移動量を示した測 点は除外した。

全体的な移動の傾向をみると, 地すべり 地の頭部 (h1, h2, h3, h4) 付近の測点の 移動ベクトルは, 地すべり地の中央部に向 けて集中していくような傾向を示す。しか し中央部から脚部 $(\mathrm{t} 1, \mathrm{t} 2, \mathrm{t} 3, \mathrm{t} 4)$ 飞至る につれて互いに逆方向に発散していく。そ の形態は脚部境界点 ( $\mathrm{t} 2$ ) の付近を境に両 側に振り分けられている。(t2) から河川 までのわずかな区間では写真上の計測では

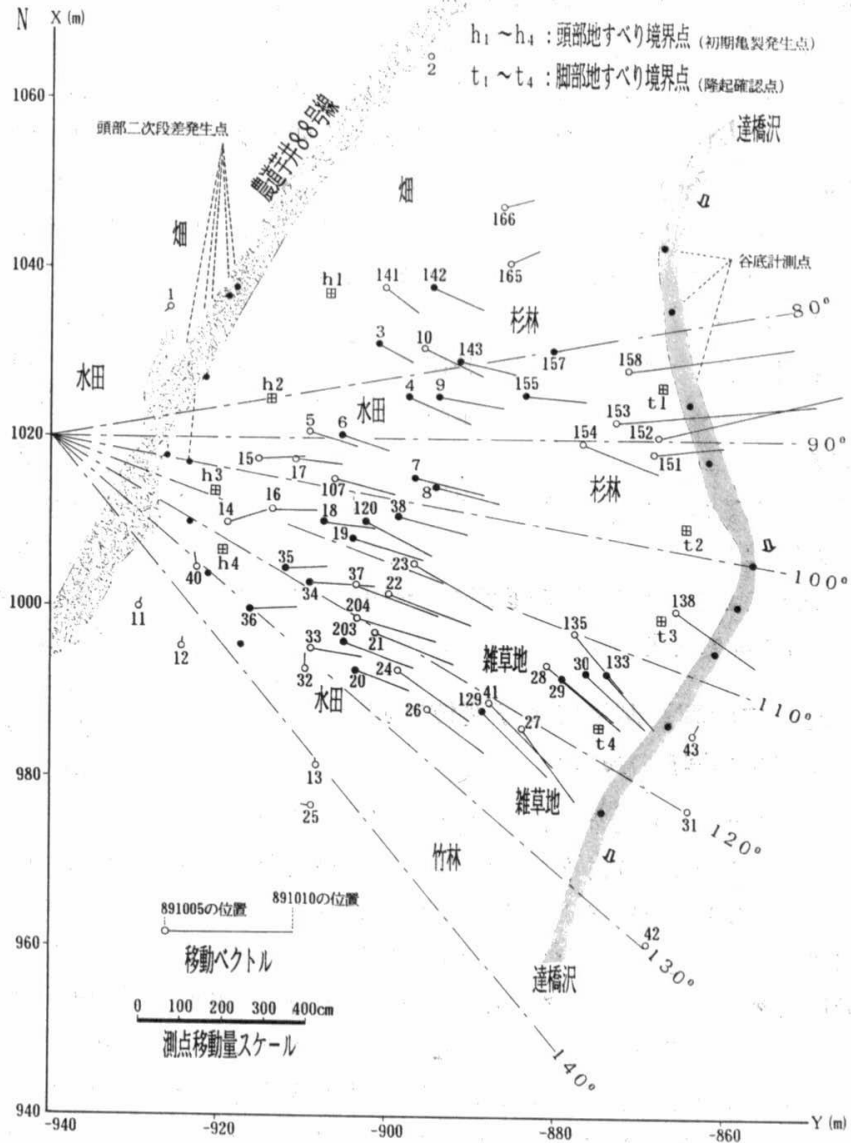

図-2 変位追跡点の配置と各測点の平面移動ベクトル（期間 : 891005 891010) $\mathrm{h} 1, \mathrm{~h} 2, \mathrm{~h} 3, \mathrm{~h} 4=$ 解析用頭部境界点 $\mathrm{t} 1, \mathrm{t} 2, \mathrm{t} 3, \mathrm{t} 4=$ 解析用脚部境界点 黒丸印は立体移動量が $150 \sim 200 \mathrm{~cm}$ の測点，白丸印はそれ以外の移動量を 示す測点 変位が喼められない。現地では（t2）の付近に円䂺や直 径 1 2 mの転石を含む河岸段丘が残っている。これが 地すべりに対する一種の抵抗体として作用しているすの と考光られる。

150 番台之 160 番台の測点は森林地帯にあるため, 樹木 の頂点を変位追跡点とした。樹木の中には地すべりに伴 って傾動するものがある。そのため図に示した移動べク トルには地すべりで押し倒されていく樹木の先端の移動 成分を含んだものもある。すなわち樹上の変位追跡点の 場合は, それが直ちに地表の移動方向を示するのとは断 定できない。

測点 $8,154,138,135,23$ で囲まれた 部分には空白 部が多い。この一帯は杉林で, 杉の木の傾動が著しいた め計測がほとんど不可能な領域である。また計測してみ ても移動量がきわめて大きく移動方向も不規則なためこ の図には示さない。

測点26，135，138を結ぶ線から谷までの区域の測点は 雑草地の中にある。雑草の隙間から地表の位置をとらえ ているため, 精度的にかなりばらつくものと予想された
が, 罒示の平面移動ベクトルの各測点の移動の傾向には 大きなばらつきは認められない。

測点23，24，26，135 で囲まれる部分は雑草が著しく 繁茂しており, 計測点を設けることができながった領域 である。

図-3は各測点の移動ベクトルを，X軸からの水平角が $100^{\circ}$ の鉿直な投影面上に投影したものである。150 番台 と 160 番台の測点群は樹木の頂部にある。その他の測点 は地表面に設けてある。この断面の方向は図 2 の各測点 の平面移動ベクトルから明らかなように, 地すべりを総 括的にみな場合の平均的な移動方向に近い。このことを 加味して図-3を観察すると, 各測点のベクトルには地下 のすべり面形状の特徴があらわれていることがわかる。

すなわち図-3に示す各測点の移動べクトルの傾きは, 斜面の頭部では急勾配を示すが中部から脚部へと移行す るにつれて徐々に勾配が緩くなり, 脚部の付近では逆勾 配となる測点もみられる。このことはこの地すべりが回 転性の地すべりであることを意味するものである。150 番台と 160 番台の樹上測点グループのみについても地上 


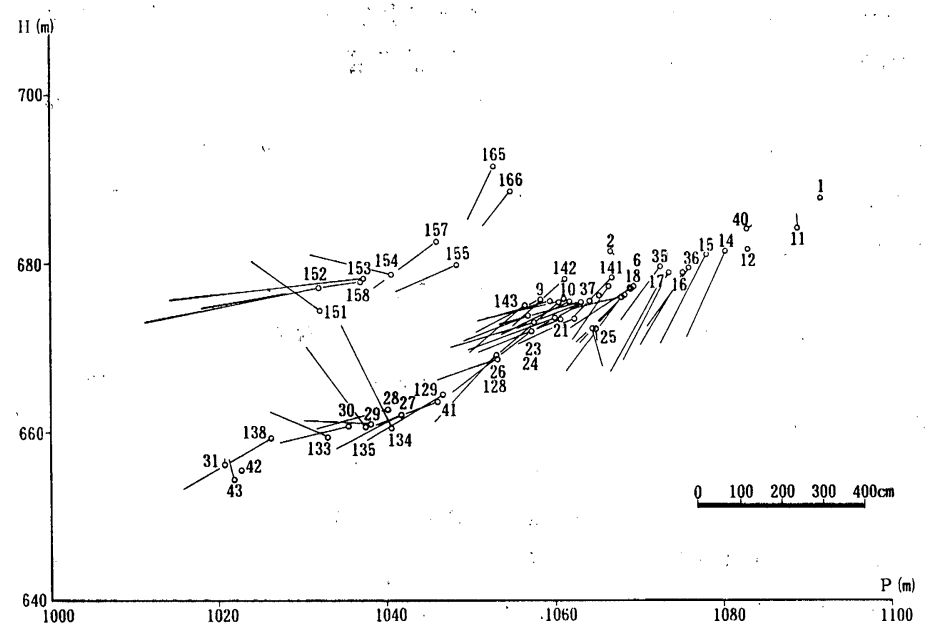

図-3 地ずべり地を側面からのぞむ投影断面図（投影面方向角 $100^{\circ}$ ) 上における各測点の 移動ベクトル（150番台と160番台のベクトルは杉の木の頂点の軌跡を示す）

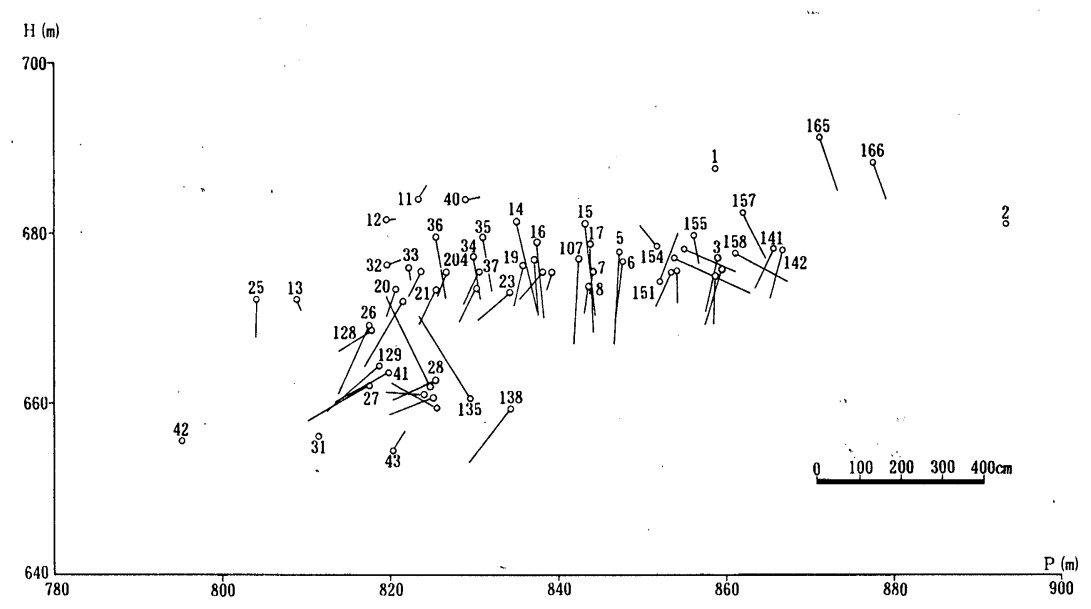

図-4 地すべり地を下方からのぞむ投影断面図（投影面方向角 $10^{\circ}$ ）上における 各測点の移動 ペクトル

測点グループと同様な回転運動的な特徵がみられる。

測点の移動ベクトルの中には全体の移動傾向とかなり かけ離れだものがある。これらは雑草地や森林地帯に設 けた測点である。雑草や樹木の枝葉が障害となって, 写 真 $\mathrm{A}$ と B の上で同一点を判別することが非常に困難であ ったためにこのよらな異常な結果が得られた。したが ってこれらの点のデータは以下の解析では除外して考兄 る。

図-4は投影面の方向角を $10^{\circ}$ とした場合の各測点の移 動ベクトルである。これは地すべりの全体的な移動方向 とほぼ直交する方向から各測点の動きを観察したもので ある。そのため上下方向の運動が卓越している。図の中 央部の測点群（左端 No.36 から右端 No142 までの範囲 に分布する上部の測点群）の動きは, 両側面から次第に 中心部に集中するような傾向を示す。このことはこの地
ナベり地の上部での土塊は， 主たる進行方向と直交する 方向から見たとき，ほぼ一 体化して微小な回転に近い 運動を示していることを意 味する。

右上方の No.165, 166 の 移動ベクトルは, 樹木が下 方に移動しながらその頂点 が地すべり地から外側に倒 れたものとみなす。またこ の図に拈いて，地すべり地 の脚部付近の杉林の頂部に 設けた 150 番台の測点の動 きは極めて不規則である。 No.152，153，158 は傾きが 著しいため, 解析用のデー タからは除外すべきもので ある。

この図の左側の中央部か ら下方にかけて分布する測 点群 (No. 21, 23, 27, 28, 138 等) の移動ベクトルは, いずれも左外側に偏位して いる。これらの測点は図-1 に怙ける標高 677.0 から 677.1m にかけて発生して いる段差の位置よりも下方 に位置する斜面上の水田や 䧴草地の中に選点したるの である。図-1の段差の発生 形態からみて, この一帯に は標高 $677 \mathrm{~m}$ 付近に水平に 延びる段差を冠頭部とした局所的な二次地すべりが発生 しているものと考える。この特性は図-2の平面移動べク トルにもよく表現されている。

\section{5. 地下すべり面形状の推定}

前章に述べたように, この地すべりの平面図上での動 きには，頭部から中央部にかけては集中性が，中央部か ら脚部にかけては発散性が観察される。また地すべりに よる現地の変動は谷の位置までは達しておらず, 谷底か ら上方の山腹 (図- 1 の $\mathrm{t} 1, \mathrm{t} 2, \mathrm{t} 3, \mathrm{t} 4)$ 飞地すべり脚部の 現象があらわれている。さらにまた地すべりの発生以前 の地形にお打る達橋沢の屈曲状況之等高線の形態（図-1) に注目すると，(t2)，(t3) の付近から河川の方向へ突出 している部分には, 河川の浸食に対して強い抵抗力をる った何らかの要因が潜在しているために, 水流を外側に 
湓曲させているものと判㜔できる。現地に抽けるこの埸 所には值径 1 $2 \mathrm{~m}$ の巨石混じりの目砂を主体とした河 岸段丘の微地形が存在する。

これらを総合すれば，この突出部分は今回の地すべり によって破壊されずに抵抗を続けており，上方から流下 する土砂を左右に分流させる作用をなしているものと考 えられる。

したがってこの地すべり地に対しては，すべての測点 の移動ベクトルを総括的に処理してすべり面の解析を行 ならといら手法は好ましくない。試みに図-2〜図-4に示 した全測点の移動ベクトルの中から，前章で述べたよう な異常な挙動を示す測点のデータを除外した上で，三次 元移動軌跡法4)によって地下のすべり曲面の立体的な形 状を求めてみた。得られた結果は，Y軸方向（全体的に 見た地すべりの移動方向にほぼ近い方向）に平行な断面 図上では下に凸の曲線形状で正常であるが，X軸方向に 平行な断面図上では上に凸の曲線形状となり，地すべり 現象を説明し得ないものとなった。よって，この地すべ り地の地下すべり面に関する解析は，各測点の移動べク トルの特性に注目して取り扱ら必要がある。
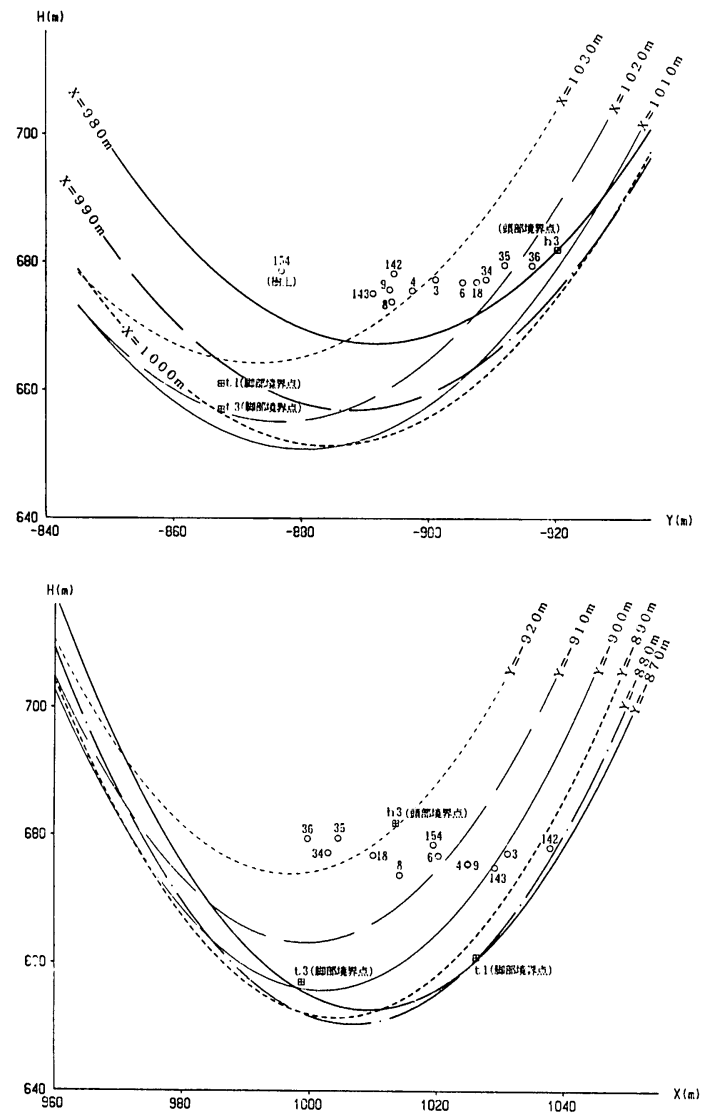

図-5 三次元移動軌跡法による地下すべり面の推定形状 (HY 面扰よび $\mathrm{HX}$ 面上への投影)

\section{1 三次元移動軌跡法によるすべり面形状と地すべ りの影響範囲の推定}

ここでは三次元移動軌跡法(解析手法は文献4)を参照) の一例として，地下すべり面の立体的な形状をひとつの 二次曲面で近似した場合の解析例を示す。

解析に用いる測点は上記の理由から，その移動特性に 注目して選定する必要がある。この解析例ではまず，変 位追跡点の中から，立体移動量 $\left(d x^{2}+d y^{2}+d h^{2}\right)^{1 / 2}$ が $150 \sim 200 \mathrm{~cm}$ の範囲の測点を選定した。選定理由は，移 動量が小さい測点のデータでは 3.3 で述べた測量誤差の 影響が大きいために解析には適さないこと，また大きな 移動量を示す杉林や雑草地のデータは前述のように信頼 度が低いことによる。ここで選定した測点の移動量は测 量誤差の10倍程度に達する。よって解析用のデータとし ては信頼できるものである。この段階で選定した測点は No.3, 4, 6, 7, 8, 9, 18, 19, 20, 29, 30, 34, 35, 36, 38, $120,129,133,142,143,155,157,203$ の合計23点であ る。これらの测点を黒い丸印で図-2に示した。

さらに図-2の移動ベクトルを観察してその移動特性に 共通な傾向のあるものとして, 測点 $3 ， 4 ， 6 ， 8 ， 9 ， 18$, 34，35，36，142，143を選ぶ。これらは地すべり地の頭 部から中部にわたる測点である。そして脚部には適当な 測点がないので, No.154 を選んだ。この測点の 移動量 は $200 \mathrm{~cm}$ 以上と大きいが，その移動方向からみてこの 解析に用い得るものと判断した。

解析の結果，すべり面（二次曲面）の方程式は次の式 形で得られた。ここで地すべりの境界点として頭部では (h3) を, 脚部では (t1) と（t3）（図-2参照）を与えて いる。

$$
\begin{aligned}
H= & 0.02696 X^{2}-0.01322 X Y+0.01785 Y^{2} \\
& -65.91347 X+44.78173 Y+53561
\end{aligned}
$$

なおこの式で $H=$ 標高 $(\mathrm{m}), X=x-75,000(\mathrm{~m}), Y=$ $y+31,000(\mathrm{~m})$ である。 $x, y$ は平面直角座標系（国家座 標系）であらわした平面図上の座標值である。

この曲面を $X$ 軸および $Y$ 軸に平行な等間隔の断面上に 投影したものを図-5に示す。解析に用いた测点および境 界点も同時に示してある。No.154 以外の諸点は地表面 に存在する。上側の図はこの地すべりの繸断面図, 下側 の図は地すべりの横断面図にほぼ匹敵する。両者とも地 すべり曲面の形状としての不自然さはないと考える。す ベり面の最低部の標高は $651 \mathrm{~m}$ で，その位置での地表面 からの深さは地形図上で調べる $14 \mathrm{~m}$ となる。しかしそ の下方の達橋沢の川底よりも $4 \mathrm{~m}$ ほど深い。これは現地 の状況から見ると多少不合理である。

図-1において実線で囲んだ領域は，この解析で得ら れたすべり曲面と地表面との交線を求め，平面図上に 地すべりの影響圈を示す境界線を推定して表示したも のである。この境界線（実線）は頭部の（h2)，(h3）に 
わたる段差とはよく対応する。これは（h3）を境界条件 として与えたから当然のことである。境界線よりも上方 の道路に至る区間の段差は, 地すべり発生時の地表変状 の発達過程 (第 2 章) から判断して副次的な局部崩落と みなしている。よって本文では, 解析に用いる頭部の境 界点 (h1)，(h2)，(h3)，(h4）を図示の位置にとった。 この境界線は地すべりの右肩部の付近では現地との整合 性がよくない。解析に用いた測点 No.142（標高点677.2 mの上方）が影響圈の外に出てしまった。しかしこの標 高点の下側に発生している段差の形状と境界線とはよく 対応している。この段差から時計回りに地すべり境界線 をたどると，(t2)，(t4）とは一致してはいないものの, この図に示された地すべり地の下半部に対する推定影響 圈はほぼ妥当なものと考兄られる。地すべり地の左肩部 では境界線と現地の段差とはかなりかけ離れている。た だしこの境界線は地形図の上では古い局部的な滑落崖の 直下にまで迫っている。このことはこの地すべりに関し て旧崩積土の再活動を類推させるところに興味がある。

三次元移動軌跡法は，パソコンを用いた地下すべり面 の推定解析には効果的に利用できる4)。しかし本研究の ように不確実性とかなりの誤差を含んだデータが多く, さらに本章の冒頭で考察したような脚部付近における部 分的な構造特性の影響を受けているらしい地すべりの場 合には, 解析データの選定に十分注意しないと解が安定 しない。本文に示したもの以外にも各種のデータを組み 合わせて解析してみたが，そのほとんどが現地の現象と の不整合に終った。ここに示したものは比較的整合性の よいものの一例に過ぎない。したがって本地すべりに三 次元移動軌跡法を適用することはむずかしい。

\section{2 投影断面図上における地下すべり面の推定}

ここでは上記の理由から, 本文で研究対象としている 地すべりについて次のような解析手法を適用する。

1）まず平面図上で各測点の移動べクトルを観察して, 地すべり挙動としての共通な特性を示す測点のグループ からなる領域を定める。

2）次にその領域内で選定した測点の移動べ クトルをいくつかの方向の鉛直投影面上に投影 し，各投影断面図上での移動べクトルを解析し て，その断面図上に拈ける地下のすべり面の位 置と形状を推定する。

3）このようにして得られた各投影断面図上 でのすべり面について，現地の境界条件（頭部 および脚部の変状）と最もよく整合するものを 採用する。

すなわちこの地すべり地に関しては，地表の 各測点の移動特性に注目して地すべり地をいく つかのブロックに分割し, 各ブロックを代表す るような移動方向を見出し, その移動方向と平
行な投影断面図の上ですべり面の形状を推定する，とい ら手法を用いたほうが合理的である。この手法によって 各種の投影断面図上に扮ける解析を試行して，現地の状 況と比較的よく整合するすのを探索した。以下にそのう ちの代表的な解析結果を示す。なお解析に用いるデータ の選定は，上記 (5.1) と同様な規準にしたがう。

図-6は多角形法2)による解析例である。これは図-2に おいて頭部境界点（h2）と脚部境界点（t2）を結ぶ線よ りも北側（図では上側）に存在する測点群のデータを用 いて解析したものである。図-2の各測点の移動ベクトル （正常なもの）を観察して，この領域に含をれる地すへ り土塊の主たる移動方向は， $X$ 軸から $90^{\circ} \sim 110^{\circ}$ の範囲 内に存在することが予想される。そこで投影面の方向角 を細かく変化させながら, 多角形法（解析手法は文献2） を参照）によってすべり面の形状を解析していく。解析 上の地すべり境界点として頭部で (h2)を, 脚部で ( t 2$)$ を選ぶ。解析の結果, 図一に示すような投影面方向角が $97^{\circ}$ の場合が頭部之脚部の解析用境界点 $(\mathrm{h} 2, \mathrm{t} 2)$ 飞対 する結合条件が最もよいことがわかった。この図におい て測点 No.151，154，155 は杉林の樹上に設けたもので ある。その他の測点は地上に設けてある。実線で示した あのが多角形法で推定したすべり面の形状である。地す ベり地の下方では測点が上記のような樹上に設けた 3 点 のみのため,すべり面形状が不自然である。これを修正 するために，多角形法で推定したすべり面の形状に二次 曲線をあてはめてみると, 破線で示すようなすべり面形 状が得られる。

図一7は最小二乗法を用いた多項式法（解析手法は文献 3)を参照）による解析例である。解析に用いた測点は図一 2 そ扣いてほほ汪頭部境界点 $(\mathrm{h} 2)$ と脚部境界点 $(\mathrm{t} 4)$ と を結ぶ線から南側（図では下側）に存在するものである。 解析の結果, 図示のような投影面方向角が $110^{\circ}$ の場合に 扣いて解析用境界点 $(\mathrm{h} 2, \mathrm{t} 4)$ 飞対寸る結合条件の最も よいものが得られる。この解析に用いた測点はいずれる

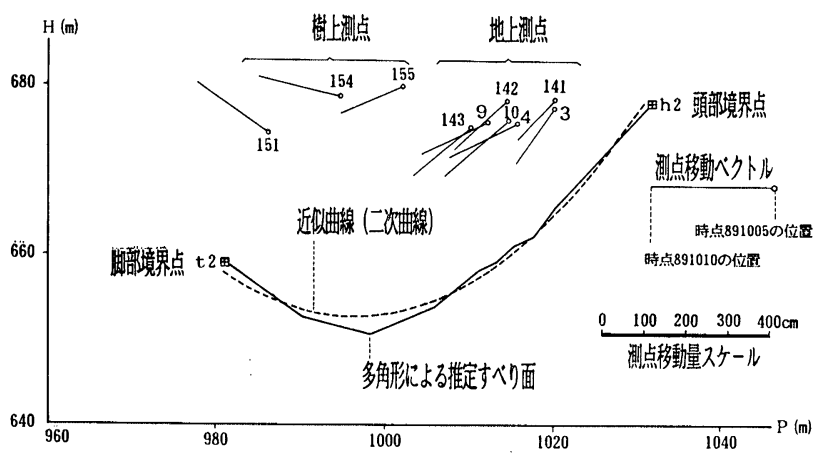

図-6 多角形法による地下すべり面の推定 （投影面方向角 $97^{\circ}$ 使用測点番号 : $3 \cdot 4 \cdot 9 \cdot 10 \cdot 141 \cdot 142 \cdot 143$. $151 \cdot 154 \cdot 155)$ 


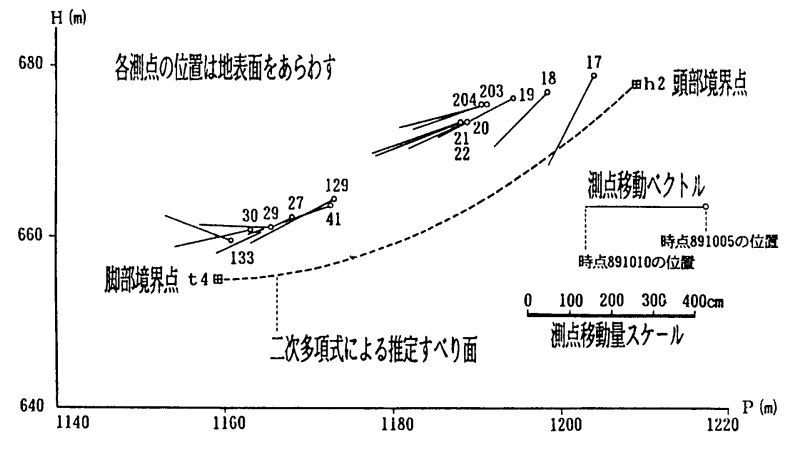

図-7多項式法による地下すべり面の推定

（投影面方向角 $110^{\circ}$ 使用测点番号 : 17・18・19・20・21・22・27 $29 \cdot 30 \cdot 41 \cdot 129 \cdot 133 \cdot 203 \cdot 204)$

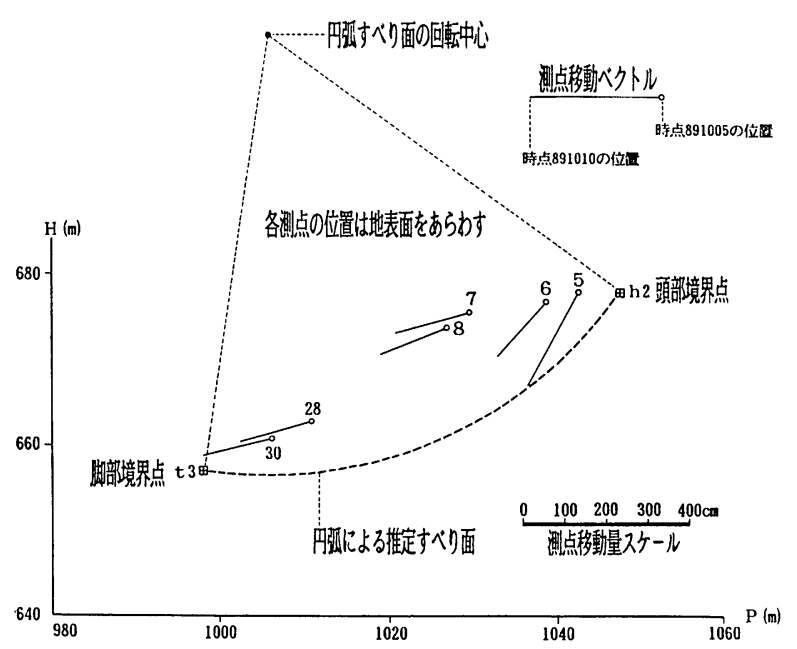

図-8 円弧すべり面法による地下すべり面の推定 （投影面方向角 $98^{\circ}$ 使用測点番号 : 5.6・7・8・28·30)

地表面に存在するものである。

上記の北側の測点群のデータを用いた場合に比べて, 南側の測点群のデータを用いた場合には，すべり面の深 さが比較的浅くなっている。

図-8は最小二乗法を用いた円弧すべり面法（解析手法 は文献1)を参照）による解析例である。解析に用いた測 点は, 地すべり地の頭部から中部にかけては測点 No.5, $6,7,8$ の 4 点である。これらの測点は図-2に見るよう にこの地すべり地のほぼ中央に位置しており, 移動べク トルの方向は河川が外側へ屈曲する頂点に向かっている。 これらの測点より下方の地すべり脚部にかけては測点が 存在しない。この空白部分は杉林で, 樹木の傾動が甚だ しくて解析用の变位追跡点データを得られなかった場所 である。この解析では脚部付近にも測点が必要なので, No.28，30 を選んだ。解析の結果は眓示のように投影面 方向角が $98^{\circ}$ のときに, 解析用境界点 $(\mathrm{h} 2, \mathrm{t} 3)$ に対す る結合条件が最もよくなる。この図に拈ける測点はいず れも地表面の位置をあらわす。すべり面の深さは北側測
点グループによるもの（図-6参照）と南側測点グ ループによるもの（図-7参照）とのほぼ中間的な 梁さとなっている。

なお図-6，7，8においてはそれぞれ異なる解 法による結果を示したが，各図について図示した もの以外の解法を適用してもほぼ同じ結果が得ら れている。

\section{6. 総 括}

本研究は, ある場所に発生した地すべりに対し て, 空中写真測量による安全で迅速な計測一解析 システムを完成させることを目的として開始した ものである。この手法を実用的なものとするため には, さらに数多くの地すべり地に対して実験的 な検討を積み重ねていく必要がある。今回の研究 を通じて知ることのできた事項を以下に要約して， 今後の研究の課題としたい。

1）現地での最初の空中写真撮影は，早期に行 ならほど利用価优がある。それは解析精度の向上 にもつながる。地すべりの兆候が現われた時点で 直ちに実行することが望ましい。

2）異なる日時に撮影した空中写真上で，地す べりで移動した地上の微小物体が同一物であるか どうかを判定するために, 移写器を利用して空中 三角測量のタイポイント選点移写の原理を適用し た。この手法によって, 移動する地すべり土塊自 体の変形の有無も判別できる。この原理は今後解 析用のデータの選定の際にも有效に利用できるも のと考える。

3）森林や雑草地に覆われて空中から地表が見 えないような場所に対する变位追跡はきわめて困難であ る。計測精度を高めるためには, 部分的な伐採等を行な わなければならない。

4）空中写真測量による変位追跡点の座標值測定の誤 差は $\pm 15 \mathrm{~cm}$ 程度である。よって地表の移動量がこの㕵 差の数倍以上に達するような地すべりでなければ本法の 適用はできない。

5）各種の投影面の上で地表物体の移動ベクトルを解 析することによって, 地すべりの移動方向と移動速度, 地すべり地内の移動ブロックの区分, 地すべりの影響し ている範囲, 地下のすべり面の梁さと形状などを求める ことができる。この際, 解析に用いるデータの選択によ ってかなりの差が生ずる。これの第一の解決策は写真測 量の精度の向上である。

6）今回の研究ではカラー写真を使用した。カラーフ ィルムはモノクロフィルムよりも解像力が 2 倍少る。計 測用にはモノクロ写真を使用し, カラーフィルムは地上 物体の判別のための補助として用いることが望ましい。 
また撮影縮尺は $1 / 2000$ 以上の大縮尺とすることが望まし い。この 2 点の改良で写真測量の精度はかなり向上する。

\section{謝 辞}

本研究を進めるにあたり，長野市役所河川課および日 本物理探鉱株式会社からは現地調査に関する種々の情報 を提供していただいた。ここに記して謝意を表します。

\section{参考文献}

1）吉澤孝和・細川容宏：地すべり地に沏ける地表変位測量デ 一夕老用いた円弧すべりの解析，地すべり, 23-4,pp.13〜
23, 1987

2）吉澤孝和：多角形法による地下すべり面の推定，地すべり， 25-2, pp.9 17, 1988

3）吉澤孝和：多項式を用いた地すべり地の地下すべり面形状 の推定, 地すべり, 25-3, pp.1 10, 1988

4）吉澤孝和：地上測量による地下すべり面形状および地すへ り影響範囲の推定, 地すへりり，26-3，pp.28～39, 1989

5）吉澤孝和・村瀬孝三 : 写真測量による地すべり地の地下す べり面の推定, 土木学会中部支部研究発表会講演概要集, $4-17,1990$

6）打荻珠男：航空写真による地すべり状況の測定，地すへり , 5-2, pp. $27 \sim 33,1968$

7）長岡正利 : 長野市地附山地すべりの災害状況と地形変化, 測量, 35-10, pp.23 31, 1985

（原稿受理日 平成 2 年 5 月 9 日）

斜面災害に関する

$$
\text { アジアミナー熊本' } 91
$$

Asian Seminar on Slope Disaster Kumamoto '91

とき:1991年 6 月26日（水）

ところ：KKR五菜閣，TEL（096）355-0121（熊本市千葉城町 3-3）

主 催 : 熊本大学自然災害研究会, 土質工学会九州支部, 土木学会西部支部

後 援: 建設省九州地方建設局, 熊本県土木部, 熊本県建設技術センター, 熊本県建設業協会, 熊本県 地質調査業協会, 建設コンサルタンツ協会九州支部

参加費：5,000円（銀行振込で下記へ御送金下さい。）

$\begin{array}{rrll}\text { プログラム } & 9: 30 \sim 14: 40 & \text { タイにおける斜面災害の状況と対策 } & \text { P. NUTARAYA (アジア工科大学) } \\ 10: 50 \sim 12: 00 & \text { 中国における斜面災害の状況と対策 } & \text { 講師未定 } \\ 13: 10 \sim 14: 20 & \text { 韓国における斜面災害の状況と対策 } & \text { 金 翔圭 (東国大学校) } \\ 14: 20 \sim 15: 30 & \text { 斜面災害軽減対策の現状と今後の展望 } & \text { 小川 裕示 (建設省) } \\ 15: 40 \sim 16: 50 & \text { 斜面崩壊子予知技術の現状と今後の展望 } & \text { 川 } \quad \text { 浩 (信州大学) }\end{array}$

郎 親 会 と き: $17: 30$ ところ:KKR五崒閣 参加費: 5,000 円（銀行振込で下記へ御送金下さい。）

熊本・大分地方の

'90 年7月豪雨災害に関する調査報告会

とき：1991年6月27日（木） ところ：KKR五峯閣，TEL (096) 355-0121

主 催: 熊本大学自然災害研究会, 九州大学西部地区自然災害資料センター

後 援: 土木学会西部支部

参加費 : 2,000円（銀行振込で下記へ御送金下さい。）

プログラム $9: 30 \sim 10: 10$ 斜面災害

$10: 10 \sim 10: 50$ 土石流災害

鈴木 敦巳（熊本大学）

$11: 00 \sim 11: 40$ 避難状況

橋本 晴行 (九州大学)

中島 重旗 (熊本大学)

申込み方法 参加者氏名, 勤務先, 連絡先, 参加対象を明記して, はがきで下記へお申し込み下さい。

連 絡 先 熊本大学自然災害研究会 アジアセミナー 熊本’91事務局 鈴木 敦巳

熊本市黒髪 2 丁目 39-1 熊本大学工学部土木環境工学科内

TEL. 096-344-2111 (3539), FAX. 096-344-5063

参加費振込銀行口座：肥後銀行子飼橋支店（普通） 1570779 